\title{
Immunohistochemical Markers \\ of Local Tissue Response to the Implantation \\ of Products Made from PHA
}

\author{
Yuri S. Vinnik ${ }^{\text {a }}$, Nadezhda M. Markelova**, \\ Ekaterina I. Shishatskayab ${ }^{b}$, Ekaterina S. Vasilenya ${ }^{a}$, \\ Nataliya S. Soloveva a and Vladimir A. Horzhevsky ${ }^{a}$ \\ ${ }^{a}$ V.F. Vojno-Yasenetsky Krasnoyarsk State Medical University \\ 1 Partizan Zheleznyak Str., Krasnoyarsk, 660022, Russia \\ ${ }^{b}$ Institute of Biophysics of SB RAS \\ 50/50 Akademgorodok, Krasnoyarsk, 660036, Russia
}

Received 13.08.2015, received in revised form 26.10.2015, accepted 14.01.2016

The paper presents the analysis of the results of application of monofilament suture based on polyhydroxyalkanoates (PHAs) in comparison with suture materials "Vicryl" and "Kaprofil" in experiment with Chinchilla rabbits. It was proved that the use of the PHA-based suture is accompanied by minimally pronounced local tissue response.

Keywords: polyhydroxyalkanoates, surgical thread, VEGF, CD68+, CD31+.

DOI: $10.17516 / 1997-1389-2015-9-1-109-120$.

(C) Siberian Federal University. All rights reserved

* Corresponding author E-mail address: markelova_nadya@mail.ru 


\title{
Иммуногистохимические маркеры \\ местной реакции тканей \\ при имплантации изделий из ПГА
}

\author{
Ю.С. Винник ${ }^{\mathrm{a}}$ Н.М. Маркелова ${ }^{a}$, Е.И. Шишацкая ${ }^{6}$, \\ Е.С. Василеня ${ }^{a}$, Н.С. Соловьева ${ }^{a}$, В.А. Хоржевский ${ }^{a}$ \\ ${ }^{a}$ Красноярский государственный медиџинский университет \\ им. проф. В.Ф. Войно-Ясенеикого \\ Россия, 660022, Красноярск, ул. Партизана Железняка, 1 \\ ${ }^{6}$ Институт биофизики СО РАН \\ Россия, 660036, Красноярск, Академгородок, 50/50
}

В статье представлен анализ результатов применения моножильного шовного материала на основе полигидроксиалканоатов (ПГА) в сравнении с шовным материалом «Викрил» и «Капрофил» в эксперименте с кроликами породы шиншилла. Доказано, что применение шовного материала на основе ПГА сопровождается минимально выраженной местной реакичией тканей.

Ключевые слова: полигидроксиалканоаты, хирургическая нить, VEGF, CD68+, CD31+.

\section{Введение}

Проблема поиска и разработки новых полимеров для создания «идеального» шовного материала до настоящего времени не утратила своей актуальности (Бонцевич, 2005). В последние десятилетия синтезировано множество новых синтетических волокон и нитей на основе полиамидов, полиэфиров, полиолефинов и других полимеров, характеризующихся высокой прочностью, эластичностью и стойкостью к инфекции. Основной функцией любого хирургического шва является обеспечение достаточно плотного, герметичного и надежного соединения ушиваемых тканей и удержание их в фиксированном положении с постоянной компрессией в течение всех этапов заживления раны, включая послеоперационный отек (Буянов и др., 2000). Это предопределяет особые требования к прочности и эластичности шовных материалов, способно- сти надежно фиксироваться хирургическим узлом. Вместе с тем шовный материал должен быть биосовместимым, атравматичным, не иметь капиллярности и фитильности, сохранять свои свойства при стерилизации и в процессе хранения (Мохов и др., 2000).

Прогресс в хирургии желудочнокишечного тракта, связанный с применением новых мощных антибактериальных препаратов, новых шовных материалов, аппаратного формирования межкишечных анастомозов, к сожалению, не решил проблемы несостоятельности швов (Тепликов и др., 2001). Восстановление непрерывности и заживление анастомоза зависит от вида шовного материала и его массы, погруженной в ткани. Защитная реакция организма на шовный материал как на инородное тело направлена на отторжение лигатур в просвет полого органа, что сопровождается развитием эрозий, или организацию 
их по линии соустья соединительной тканью. Этот процесс заживления длительный, представляет собой воспалительную реакцию и определяет непосредственный исход сформированного соустья, а в отдаленном периоде его функциональное состояние. Многие авторы подчеркивают, что наиболее выраженная реакция как отторжения, так и организации лигатур происходит на нерассасывающийся шовный материал. Все это оправдывает стремление хирургов к применению биодеградируемых нитей, обладающих очевидными преимуществами (Александров и др., 1991).

Для рассасывающихся нитей характеристиками первостепенной важности являются сохранение прочности до формирования надежного и герметичного рубца, а затем быстрое удаление полимера и продуктов его биодеструкции из организма (Шишацкая и др., 2004).

Несмотря на значительные успехи, достигнутые в биотехнологии, пока не удалось создать материалы, полностью совместимые с живым организмом (Volova et al., 2003). Основным фактором, сдерживающим широкое применение остро востребованных биоразрушаемых полимеров, является небогатый ассортимент последних, а также вопросы регулируемости процессов их функционирования и деструкции в тканях (Shishatskaya, 2007).

Открытие и изучение полигидроксиалканоатов (ПГА) - полиэфиров микробиологического происхождения, стало значимым событием в биотехнологии новых материалов (Volova et al., 2004). Исследование ПГА активно проводится повсеместно, однако многие ключевые вопросы биотехнологии и материаловедения ПГА остаются открытыми. Разработанный в Институте биофизики СО РАН (ИБФ СО РАН) способ получения высокоочи- щенных образцов ПГА, создание на его основе экспериментальных изделий обеспечили возможность проведения медико-биологических исследований.

Цель работы - изучение местной реакции тканей при имплантации изделий из ПГА с использованием иммуногистохимических маркеров.

\section{Материалы и методы}

Работа выполнена в экспериментальной лаборатории кафедры общей хирургии им. проф. М.И. Гульмана Красноярского государственного медицинского университет им. профессора В.Ф. Войно-Ясенецкого (КрасГМУ). Дизайн исследования одобрен локальным этическим комитетом организации.

Исследованы экспериментальные образцы ПГА (гомополимер 3-гидроксимасляной кислоты), полученные в лаборатории биотехнологии новых биоматериалов Сибирского федерального университета с использованием лабораторного автоматизированного комплекса BioFlo (NewBrunswek, США) на опытном производстве, созданном и функционирующем при ИБФ СО РАН. Опытное производство имеет сертификат соответствия Главной санитарной службы РФ соответствия условий производству материалов для медицины (№ 24.49.05.000.М.007682.01.05 от 24.01.2005).

Моножильный шовный материал (рис. 1) получен с использованием лабораторного мини-эктсрудера фирмы Brabender (Германия) по разработанной технологии. Зарегистрированная торговая марка ПГА и изделий из него, получаемых в ИБФ СО РАН, - Биопластотан (Торговая марка «БИОПЛАСТОТАН». Регистрационное свидетельство № 315652 Федерального института патентной экспертизы по заявке № 2006703271/50, приоритет от 15.02.2006. Классы МКТУ: 01, 05,10). 


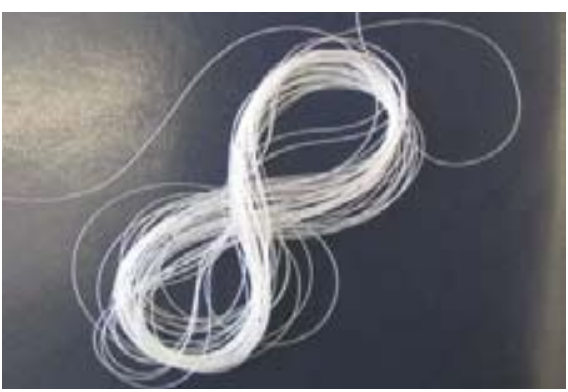

a

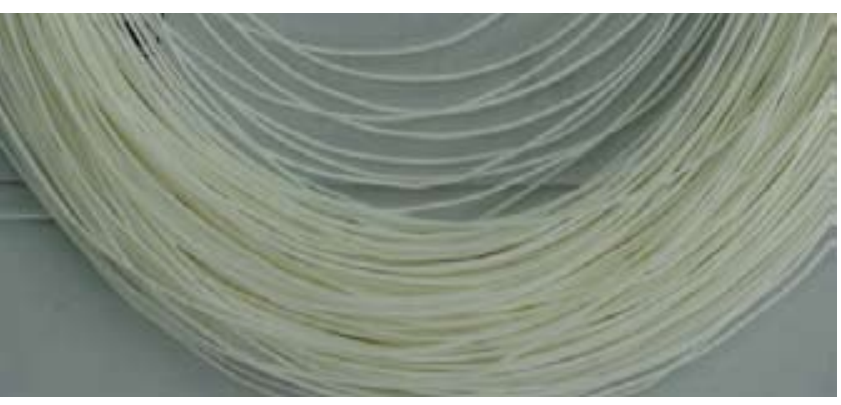

6

Рис. 1. Внешний вид монофиламентных ориентированных волокон, полученных экструзией из расплава ПЗГБ, диаметр 0,1 мм; а - натуральные размеры; б - увеличение в 4 раза

Таблица 1. Характеристика экспериментальных групп

\begin{tabular}{|c|c|c|c|c|}
\hline \multirow{2}{*}{ Группа } & Подгруппа & $\begin{array}{c}\text { Тип шовного } \\
\text { материала }\end{array}$ & $\begin{array}{c}\text { Длительность } \\
\text { эксперимента (дни) }\end{array}$ & $\begin{array}{c}\text { Количество } \\
\text { животных (n) }\end{array}$ \\
\hline \multirow{3}{*}{1} & А & Викрил & 30 & 10 \\
\cline { 2 - 5 } & В & Викрил & 120 & 10 \\
\cline { 2 - 5 } & С & Викрил & 180 & 10 \\
\cline { 2 - 5 } & А & Капрофил & 30 & 10 \\
\cline { 2 - 5 } & В & Капрофил & 120 & 10 \\
\hline \multirow{3}{*}{3} & С & Капрофил & 180 & 10 \\
\cline { 2 - 5 } & В & ПГА* & 120 & 10 \\
\hline
\end{tabular}

Примечание: * ПГА - шовный материал из полигидроксиалканоатов.

Исследование проводили на 90 кроликах породы шиншилла, содержавшихся в стандартных условиях вивария при естественном освещении со свободным доступом к пище и воде. В зависимости от типа использованного шовного материала были сформированы 3 группы. В каждой из групп были выделены 3 подгруппы с различными сроками вывода животного из эксперимента - 30, 120 и 180 дней. Характеристики групп приведены в табл. 1.

Оперативное вмешательство проводили в виварии КрасГМУ под ингаляционным наркозом в стандартных условиях. На правом бе- дре делали продольный разрез кожи и мышцы длиной 1,5-2,0 см. На мышцу накладывали, в зависимости от группы, три шва, используя один из исследуемых шовных материалов. Кожа ушивалась шёлком. Животные выводились из эксперимента путем струйного внутривенного введения раствора тиопентала натрия.

При секционном исследовании оценивали состояние швов (сохранность шовного материала, состояние окружающей мышечной ткани). Морфологическому и иммуноморфологическому исследованию подвергали фрагменты мышцы с наложенными 
швами. Материал фиксировали в забуференном $10 \%$-м нейтральном формалине и обрабатывали по общепринятой методике. Парафиновые срезы стандартной толщины (5,0 мкм) окрашивали гематоксилином и эозином, пикрофуксином по ван-Гизон, а также по Гимзе. Микроскопическое исследование и фотографирование проводили с применением светового микроскопа Carl Zeiss Axiostar (Germany) с адаптированной цифровой фотокамерой smcPentaxOptio A30. Измерение линейных размеров (оценивались в мкм), а также удельных объемов (\%) осуществляли с применением программного обеспечения Image Tool UTHSCSA v. 3.0 для среды Windows XP. Поле зрения при увеличении микроскопа х100 составило 202459,64 мкм².

Верификация макрофагов выполнена посредством иммуногистохимического анализа с применением моноклональных антител к CD68 антигену макрофагов (клон: MAC 387; тип: мышиные антимакрофагальные, неконьюгированные; кроссреактивные к человеку, крысам, кроликам; изотип: IgG1; специфичность: макрофаги; производитель: Abcam, США). Учитывали позитивное внутрицитоплазматическое гранулярное окрашивание в клетках с морфологией макрофагов. Для верификации сосудов применялись антитела в отношении CD31 (клон: [JC/70A] (ab9498); тип: мышиные антикроличьи, неконъюгированные; кроссреактивные к человеку; специфичность: связывается с $100 \mathrm{kDa}$ гликопротеином, экспрессируемым эндотелиоцитами и тромбоцитами/мегакариоцитами; производитель: Abcam, США).

Для оценки активности процессов ангиогенеза в зоне наложенного на мышцу шовного материала исследовали уровень экспрессии фактора роста эндотелия сосудов (VEGF). Экспрессию VEGF оценивали с помощью иммунофлуоресцентной реакции с антителами к VEGF (клон: [VG-1] (ab1316); тип: мышиные неконъюгированные; специфичность: связывается с изоформами - 121, - 165 и - 189 фактора роста эндотелия сосудов; производитель: Аbcam, США).

Результаты иммуногистохимической реакции оценивали полуколичественным методом.

Статистическая обработка полученных данных выполнялась при помощи программы Statistica 6.0 (StatSoft). Достоверность различий качественных признаков независимых групп определялась по $\chi^{2}$-критерию Пирсона с поправкой Йеитса. Достоверность различий количественных признаков независимых групп определялась по U-критерию Манн-Уитни. Уровень различий при $\mathrm{P}<0,05$ рассматривался как статистически значимый. Для определения корреляционных зависимостей применялся коэффициент ранговой корреляции Спирмена $\left(\mathrm{r}_{\mathrm{s}}\right)$ с определением 95\%-го доверительного интервала.

\section{Результаты и обсуждение}

Комплексная оценка патоморфологических изменений, возникающих в зоне ушивания мышечных ран кроликов с помощью шовного материала викрил, позволила выявить следующие закономерности. На ранних сроках (30 сут) преобладали процессы воспаления с явным смещением в сторону альтерации, проявляющиеся некрозами и последующими продуктивными реакциями. Финальным этапом (180-е сут) стала неполная репарация с развитием фуксинофильной грубоволокнистой оформленной соединительной ткани. При этом на всем сроке эксперимента сохранялась в различной степени выраженная воспалительная инфильтрация и дистрофические изменения фиброзной ткани. Оценка сосудистого компонента свидетель- 
ствует о незначительном развитии сосудов в зоне повреждения мышечной ткани.

Таким образом, при использовании викрила на начальных этапах преимущественным типом реакции была воспалительная инфильтрация макрофагами с формированием обширных некрозов. Проявлением реакции отторжения трансплантата (в эксперименте шовный материал) служит формирование гигантских многоядерных клеток инородных тел. На более поздних сроках эксперимента одновременно с процессами резорбции шовного материала начинаются и в дальнейшем прогрессируют явления репарации, обнаруживающие себя преимущественно перифокальным фиброзированием. Сосудистые реакции в основном характеризовались функциональными изменениями, такими как полнокровие в сосудах капиллярного и венулярного типа. При этом количество сосудов в различные сроки эксперимента оставалось относительно постоянным. Следует лишь отметить статистически не подтвержденную тенденцию к увеличению удельного объема сосудов на 120-е сутки эксперимента с последующим его снижением (рис. 2). Изменение плотности васкуляризации ткани в зоне операционного вмешательства находится как под влиянием VEGF, образуемого интерстициально расположенными фибробластоподобными клетками, так и под влиянием иных факторов, ассоциированных с макрофагами. Это наблюдение не исключает вероятности опосредованного влияния макрофагов на процессы ангиогенеза. Финальным явлением в зоне наложенных швов на 180-е сутки эксперимента стало полное замещение воспалительно-некротического инфильтрата хорошо выраженной фиброзной тканью с резорбцией шовного материала.

Преимущественным типом репаративных реакций было разрастание грубоволокнистой фиброзной ткани, расположенной интерстициально между пучками поперечнополосатой мышечной ткани. Вблизи роста фиброзной ткани мышечные клетки субъективно выглядели несколько утолщенными с подчеркнутой поперечной исчерченностью,

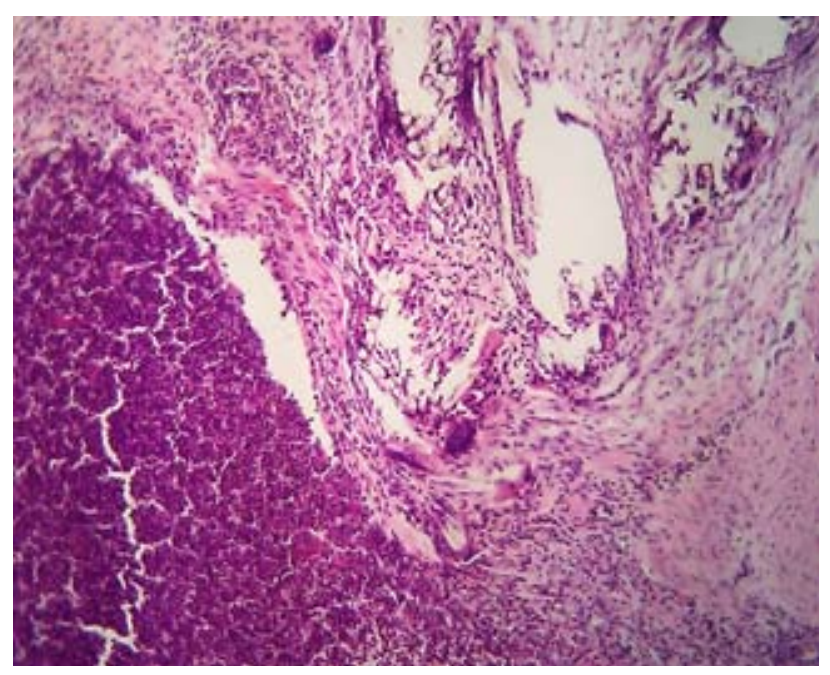

Рис. 2. Зона коагуляционного некроза возле шовного материала на 120 -е сутки наблюдения. В составе воспалительного инфильтрата - клетки с морфологией макрофагов и клетки, напоминающие эпителиоидные с гигантскими многоядерными клетками инородных тел. Окраска гематоксилин-эозин; x 200 
что, вероятно, следует расценивать как проявление посттравматической регенераторной гипертрофии (рис. 3).

При использовании для ушивания мышечных ран у кроликов не менее распространенного в клинической практике шовного материала капрофила на ранних сроках (30 сут) преобладали альтеративные воспалительнонекротические реакции, проявляющиеся коагуляционными некрозами и воспалением, с последующей инфильтрацией макрофагами и гистиоцитами (в редких случаях гранулематозным воспалением). Завершающим этапом репаративных процессов были фибротические процессы, достигающие максимума на 180-е сутки. В течение всего эксперимента сохранялись в различной степени выраженности воспалительная инфильтрация и дистрофические изменения фиброзной ткани.

Внутригрупповые изменения при использовании в эксперименте шовного материала капрофил подтвердили стереотипность изменений, возникающих в зоне нахождения шовного материала (рис. 4). Преобладающим типом реакций на 30-120-е сутки эксперимен- та являются альтеративно-воспалительные процессы, сменяющиеся в последующем на процесс репарации с нарастанием фибротических реакций.

Очевидно, что фактором активации макрофагально-гистиоцитарного звена иммунных реакций служит шовный материал, деградация которого сопровождается очагами гранулематозно-некротического типа, содержащими макрофаги, эпителиоидные и гигантские многоядерные клетки типа инородных тел. Активность макрофагального звена иммунитета обусловливает практически полную резорбцию шовного материала уже на 120-е сутки эксперимента и отсутствие шовного материала на 180-е сутки исследования. Выраженность воспалительной инфильтрации определяет в дальнейшем развитие фиброзной ткани. Вероятным отражением активной выработки VEGF на 120-е сутки эксперимента выступает усиление васкуляризации зоны повреждения с последующим снижением количества сосудов, что объясняется нарастающим фиброзированием.

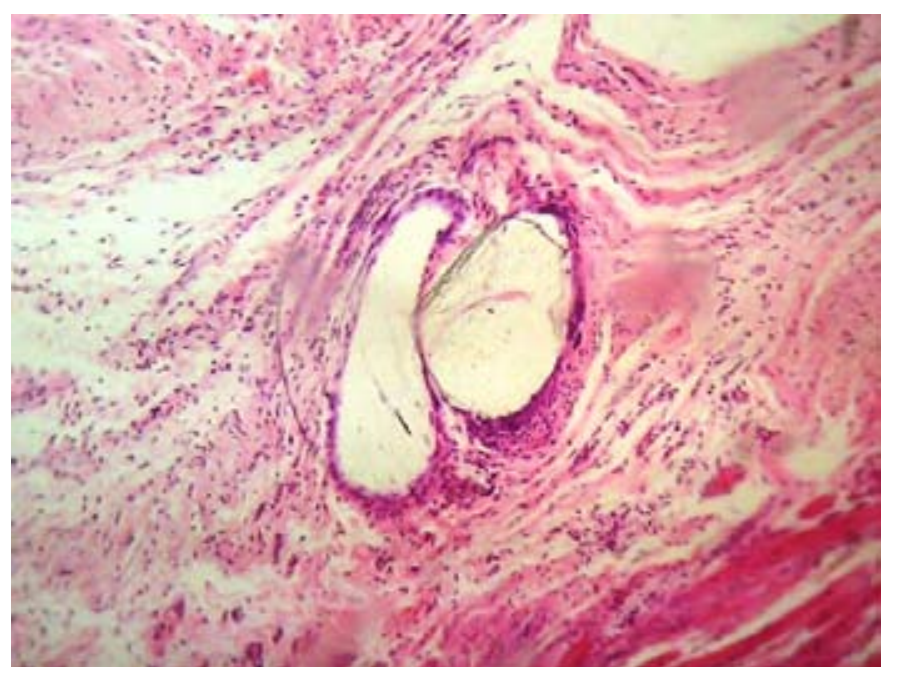

Рис. 3. Разрастание грубоволокнистой фиброзной ткани, окружающей шовный материал, в виде кристаллоидных структур. Окраска гематоксилин-эозин; х 200 


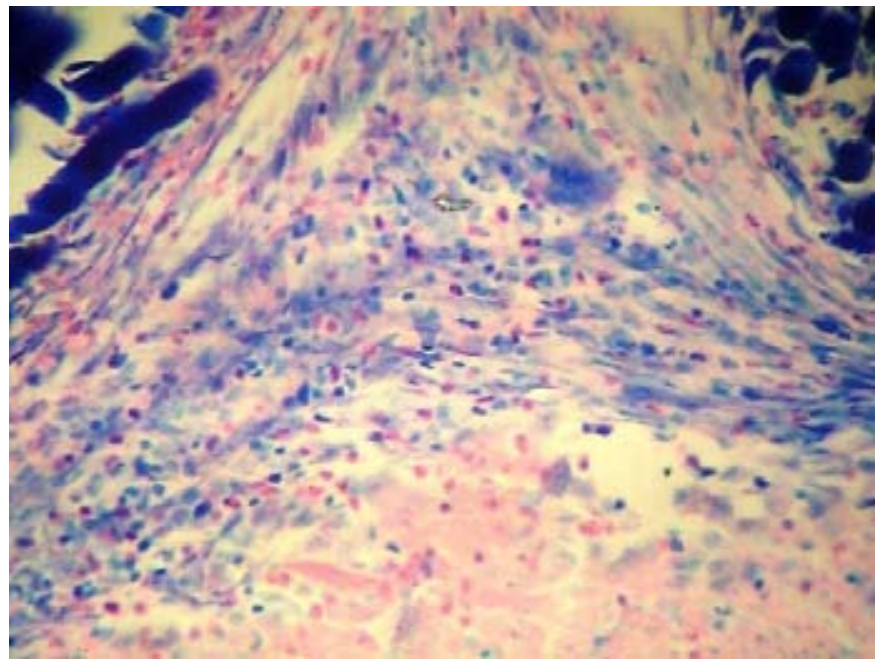

Рис. 4. Эозинофильные лейкоциты в составе воспалительно-клеточного инфильтрата; фрагмент шовного материала. Окраска по Гимзе; х 200

Принципиально отличающиеся результаты были получены при изучении взаимодействия тканей с шовным материалом у животных, раны которых были ушиты экспериментальными ПГА-нитями. Изменения, возникающие на ранних сроках эксперимента, характеризовались минимальной макрофагально-гистиоцитарной инфильтрацией с формированием в ряде случаев хорошо выраженной гигантоклеточной реакции иммунитета. При этом уже на 120-е сутки в результате биодеградации и, вероятно, макрофагальной резорбции материала без формирования обширных гнойно-некротических очагов происходила частичная резорбция шовного материала. В участках, ранее содержавших шовные элементы, формировалась зона разрастающейся фиброретикулярной зоны с минимальной лимфогистиоцитарной инфильтрацией без признаков диффузного коллагенообразования. В этой связи можно говорить о преобладании на протяжении всего срока эксперимента процессов репарации над процессами альтерации. Применение в эксперименте
ПГА-нитей в ранние сроки (30 сут) сопровождалось активацией макрофагального звена иммунитета с увеличением количества CD68+ макрофагов, а также появлением в воспалительном инфильтрате гигантских многоядерных клеток типа инородных тел.

При этом во всех случаях такая инфильтрация носила очаговый характер и не распространялась на окружающие ткани, что подтверждают данные морфометрического анализа. Формирующаяся фибро-ретикулярная капсула в окружении шовного материала достигала своего максимума к 120-м суткам и в последующем оставалась практически в неизменном виде. Минимальные изменения вокруг швов, по-видимому, связаны не только с антигенными свойствами материала, но также с особенностями биодеградации. Сохраняющийся до 30 суток эксперимента шовный материал частично подвергался биодеградации только на 180-е сутки эксперимента (рис. 5), что снижало антигенную нагрузку, не приводило к нарастанию воспалительной макрофагальной реакции и предупреждало 


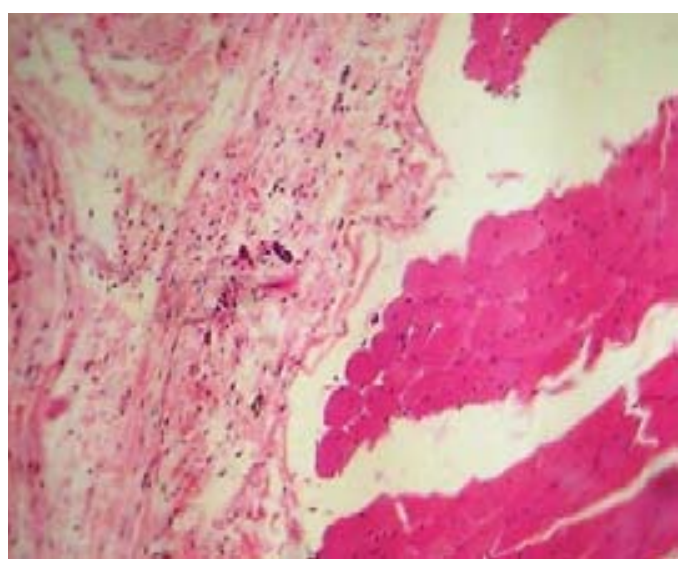

A

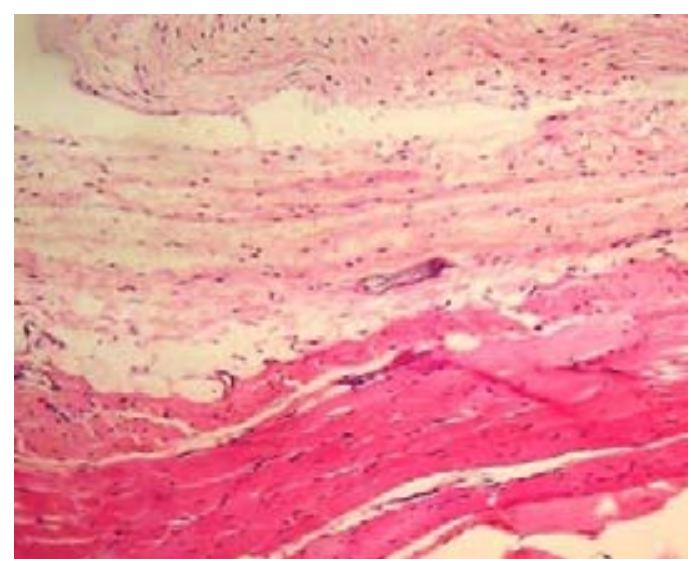

Б

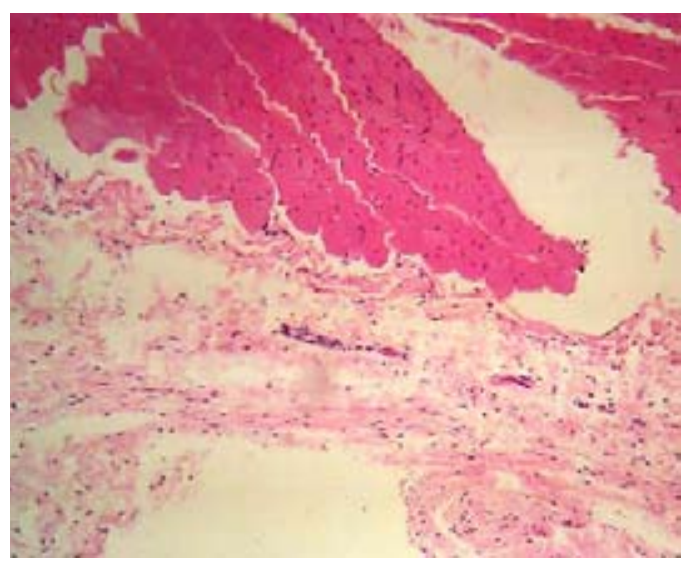

B

Рис. 5. А, Б - нити ПГА-содержащего шовного материала, визуализирующиеся в виде небольших фрагментов кристаллоидных структур, без признаков перифокального воспаления среди фиброретикулярной стромы. В - зона с полной резорбцией шовного материала с умеренным развитием фиброретикулярной стромы и наличием тонкостенных капиллярного типа сосудов. А, Б - увеличение х200; В - увеличение $\mathrm{x} 400$; окраска гематоксилин-эозин

интенсивность перифокальных фибротических реакций. В этой связи конечные этапы репаративного процесса не сопровождались значимыми структурными изменениями в мышечно-фасциальном лоскуте. В большинстве случаев к 180-м суткам (а в ряде наблюдений и к 120-м суткам) невозможно было выделить какие-либо признаки, указывающие на факт ранее выполненного вмешательства.
Согласно результатам выполненного статистического анализа выявлены достоверные различия в уровне экспрессии VEGF между 30-ми сутками и последующими сроками $(\mathrm{P}<0,05)$ (рис. 6). Тогда как различий между 3В (120-е сутки) и 3С (180-е сутки) выявлено не было. В последних двух группах данный показатель был одинаково высок в сравнении с группой $3 \mathrm{~A}$ (30-е сутки). При проведении корреляционного анализа была выявлена 


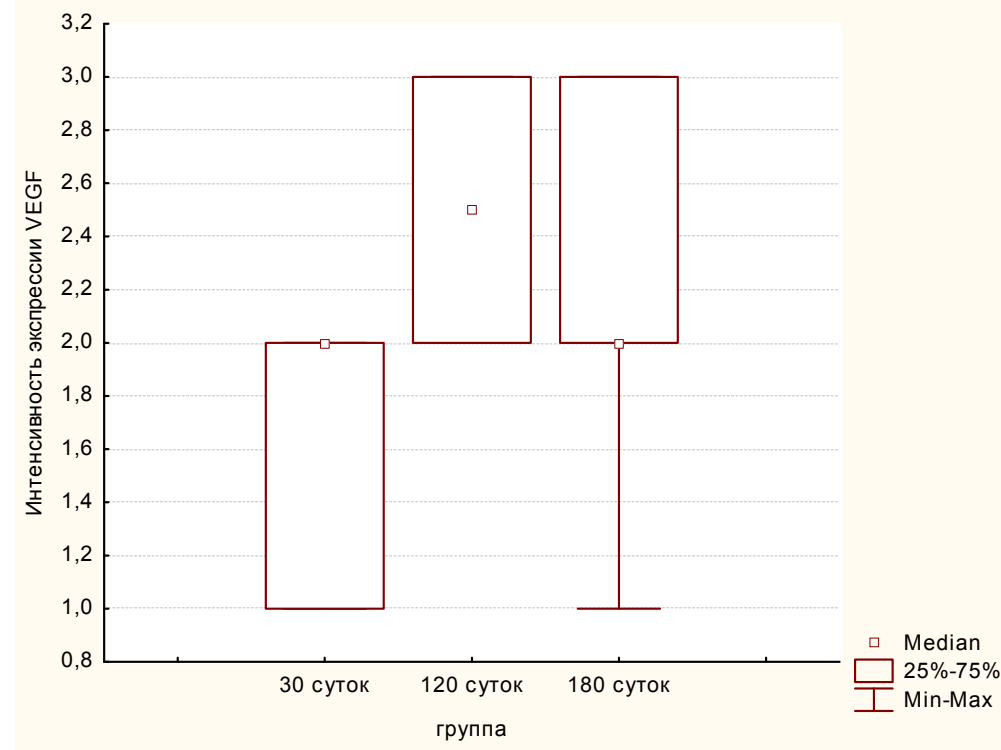

Рис. 6. Интенсивность экспрессии VEGF в различных экспериментальных группах при использовании ПГА-содержащего шовного материала

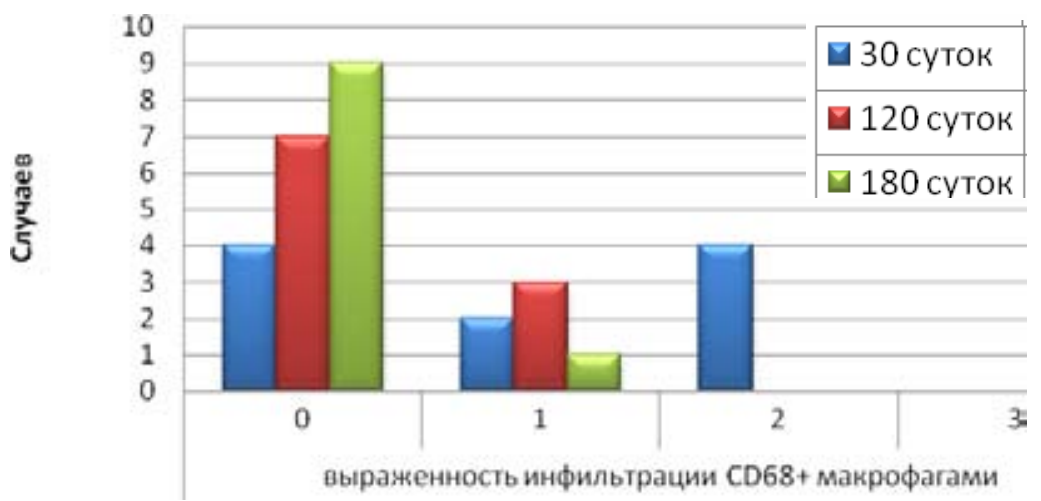

Рис. 7. Выраженность инфильтрации CD68-позитивными макрофагами мышечно-фасциального лоскута при использовании ПГА-содержащего шовного материала в различные сроки

выраженная положительная корреляционная связь между уровнем экспрессии VEGF и удельным объемом CD31+ эндотелиоцитов в течение всего эксперимента. При этом нарастание числа CD68+ клеток в исследуемом субстрате сопровождалось снижением экспрессии VEGF и удельного объема CD31+ клеток. Оценка уровня перифокальной инфильтрации CD68+ макрофагами показала, что в подавляющем большинстве случаев макрофаги обнаруживались на первом и втором этапах эксперимента (рис. 7).

Важно отметить, что при ушивании ран нитью из ПГА выраженной инфильтрации CD68+ макрофагами не обнаруживалось ни на одном из этапов эксперимента. Уже на 120 -е сутки исследования лишь в небольшом количестве случаев (30 \%) отмечалась слабая 
инфильтрация макрофагами. Сравнительный анализ позволяет говорить об отсутствии статистически значимых различий в инфильтрации макрофагами между группами $3 \mathrm{~B}$ и $3 \mathrm{C}(\mathrm{P}>0,05)$; тогда как между $3 \mathrm{~A}$ и $3 \mathrm{~B}(\mathrm{P}<$ $0,05)$, а также $3 \mathrm{~A}$ и $3 \mathrm{C}(\mathrm{P}<0,05)$ эти различия наблюдались. Такие показатели подтверждают отсутствие прямой заинтересованности CD68+ клеток в продукции VEGF и в то же время могут указывать на их опосредованное влияние на ангиогенез. Повышение уровня инфильтрации макрофагами сопровождалось нарушением корреляционных связей между уровнем экспрессии VEGF и удельным объемом CD31+ клеток. Межгрупповое сопоставление уровня экспрессии фактора роста эндотелия сосудов (VEGF) свидетельствует о большем уровне экспрессии этого ростового фактора в течение всего эксперимента при использовании ПГА-нитей в сравнении с другими биодеградируемыми материалами. Детальное гистоморфологическое исследование позволило сформировать представление об особенностях взаимодействия изучаемого шовного материала с тканями и расширить потенциальный диапазон его применения.

\section{Заключение}

Применение в эксперименте ПГА-нитей для ушивания мышечно-фасциальных ран сопровождается минимально выраженной макрофагально-гистиоцитарной инфильтрацией (30\%) и некротическими реакциями в ранние сроки (10 \%) с последующей биодеградацией к 180-м суткам эксперимента без выраженных местных клеточных иммунных реакций. В сравнении с синтетическими рассасывающимися шовными материалами при применении ПГА-нитей меньше выражено разрастание рубцовой фиброзной ткани. При использовании шовного материала ПГА на всех сроках эксперимента в зоне повреждения тканей более интенсивно развивается сосудистая сеть (в 2 раза) и выше экспрессия фактора роста эндотелия сосудов (VEGF) (в 1,3 раза), чем в группах с использованием синтетических рассасывающихся шовных материалов.

Работа выполнена за счет средств государственного задания на проведение фундаментальных исследований РАН (проект № гос. регистрации 01201351505).

\section{Список литературы}

Александров К.Р., Воленко А.В., Васина Т.А. (1991) Пролонгированное антибактериальное действие шовных материалов с полимерным покрытием. Антибиотики и химиотерапия 11: 37-40 [Aleksandrov K.R., Volenko A.V., Vasina T.A. (1991) Prolonged antibacterial action of polymer coated suture materials. Antibiotics and Chemotherapy [Antibiotiki i himioterapiya], 11: 37-40 (in Russian)]

Бонцевич Д.Н. (2005) Хирургический шовный материал. М., Интеграция, 118 с. [Bontsevich D.N. (2005) The surgical suture material. Moscow, Integration, 118 p.]

Буянов В.М., Егиев В.Н., Егоров В.И. (2000) Однорядный непрерывный шов в абдоминальной хирургии. Хирургия, 4: 13-18 [Buyanov V.M., Yegiyev V.N., Yegorov V.I. (2000) Single row continuous suture in abdominal surgery. Surgery [Hirurgiya], 4: 13-18 (in Russian)]

Мохов Е.М., Беганский С.И., Аскеров Э.М. (2000) О профилактике гнойных осложнений после операций по поводу распространенного перитонита. Тезисы докладов Всероссийской конференциии хирургов, посвященной 80-летию Р.П. Аскерханова. Махачкала, c. 141-142 [Mokhov 
E.M., Beganskaya S.I., Askerov E.M. (2000) On the prevention of septic complications after surgery for diffuse peritonitis. Abstracts of the all-Russian conference of surgeons dedicated to the 80th anniversary of R.P. Askerhanova. Makhachkala, p. 141-142 (in Russian)]

Тепликов А.В., Сандаков П.Я., Шадрин В.В. (2001) Выбор шовного материала в желудочнокишечной хирургии. Материаль IV Международной конференции «Современные подходы к разработке и клиническому применению эффективных перевязочных средств, шовных материалов и полимерных имплантатов». Москва, с. 203-204 [Teplikov A.V., Sandakov P.Y., Shadrin V.V. (2001) The choice of suture material in gastrointestinal surgery. Proceedings of the IV International Conference "Modern approaches to the development and clinical application of efficient bandages, sutures and polymeric implants". Moscow, p. 203-204 (in Russian)]

Шишацкая Е.И., Гордеев С.А., Волова Т.Г. (2004) Исследование свойств полигидроксиалканоатов, перспективных для получения пористых матриц. Перспективные материалы, 5: 40-44 [Shishatskaya E.I., Gordeev S.A., Volova T.G. (2004) Investigation of the properties of polyhydroxyalkanoates looking to get a porous matrix. Advanced Materials [Perspektivnye materialy], 5: 40-44 (in Russian)]

Volova T.G., Shishatskaya E.I., Sevastianov V.I, Efremov S.N., Mogilnaya O.A. (2003) Results of biomedical investigations of PHB and PHB/PHV fibers. Biochem. Eng. J., 16 (2): 125-133

Shishatskaya E.I. (2007) Biodegradable PHAs: production, biomedical investigations, applications. 4th Europen Congress on Biopolymers. Turkey, Kusadasi, p.32

Volova T.G., Shishatskaya E.I., Sevastianov V.I., Efremov S.N., Mogilnaya O.A. (2004) Tissue response to the implantation of biodegradable polyhydroxyalkanoate sutures. J. of Material Science: Material in medicine, 15 (6): 719-728 